\title{
THE PUBLIC SECTOR'S PERSPECTIVE ON PROCURING PUBLIC WORKS PROJECTS - COMPARING THE VIEWS OF PRACTITIONERS IN HONG KONG AND AUSTRALIA
}

\author{
Esther Cheung $^{1}$, Albert P. C. Chan ${ }^{2}$ and Stephen Kajewski ${ }^{3}$ \\ ${ }^{1,2}$ Department of Building and Real Estate, The Hong Kong Polytechnic University, \\ Hung Hom, Kowloon, Hong Kong, China \\ ${ }^{3}$ School of Urban Development, Built Environment and Engineering, \\ Queensland University of Technology, Australia \\ E-mails: ${ }^{1}$ bsesther@polyu.edu.hk; ${ }^{2}$ bsachan@polyu.edu.hk; ${ }^{3}$ s.kajewski@qut.edu.au \\ Received 24 Dec 2008; accepted 17 Sept 2009
}

\begin{abstract}
Hong Kong has been one of the early jurisdictions to adopt Public Private Partnership (PPP) model for delivering large public infrastructure projects. The development of this procurement approach in Hong Kong has followed an intricate path. As such, it is believed that there are a number of areas which are interesting to unveil. As part of a comprehensive research study looking at implementing PPPs, interviews with experienced local industrial practitioners from the public sector were conducted to realize their perspective on the topic of procuring public works projects. Amongst these interviews, fourteen were launched government officials and advisers. The interview findings show that the majority of the Hong Kong and Australian interviewees had previously conducted some kind of research in the field of PPP. Both groups of interviewees agreed that "PPPs gain private sector's added efficiency/expertise/management skills" when compared to projects procured traditionally. Also, both groups of interviewees felt that projects best suited to use PPP are those that have an "Economic business case". The interviewees believed that "Contractor's performance" could be used as key performance indicators for PPP projects. A large number of critical success factors were identified by the interviewees for PPP projects; two of these were similar for both groups of interviewees. These included "Project objectives well defined" and "Partnership spirit/commitment/trust". Finally it was found that in-house guidance materials were more common in the organizations of the Australian interviewees compared to the Hong Kong ones. This paper studies the views of the public sector towards the topic of PPPs in Hong Kong and Australia, which helps to answer some of the queries that both academics and the private sector in these jurisdictions are keen to know. As a result the private sector can be more prepared when negotiating with the public sector and realise their needs better, academics on the other hand are provided a wider perspective of this topic benefiting the research industry at large.
\end{abstract}

Keywords: Public Private Partnerships (PPP), Procurement, Public Sector Interviews, Hong Kong, Australia.

\section{Introduction}

Public Private Partnership (PPP) is a procurement approach where the public and private sector join forces to deliver a public service or facility. In this arrangement normally both the public and private sector will contribute their expertise and resources to the project and share the risks involved. The definition of PPP may differ slightly between different jurisdictions, depending on which part of the arrangement the importance is focused on. But in general PPPs can be any agreement where the public and private sectors work together to deliver a public project. PPP is a relatively modern term for this arrangement used only more commonly in the last decade. Previously different variations of the arrangement included Private Finance Initiative (PFI), which is a more familiar term to many people due to its popular development in the United Kingdom (U.K.) during the early nineties (Tieman 2003). It would not be incorrect to say that the PFI practice developed in the U.K. raised the world's attention to this alternative option for delivering public infrastructure and services. The extent to which PFI could be used and the advantages created were the main drivers attracting other countries to start adopting or improve their practice in PPP. A more specific term used more commonly a decade ago is Build Operate and Transfer (BOT). This arrangement was commonly adopted for transportation projects. This is because transportation projects tend to be larger in size and also because their long physical lives fit well into the procurement mode. Earlier this century, concession was a common form of PPP. These early concessions mainly occurred in Europe (particularly in France) for water projects (Grimsey and Lewis 2004). Although water projects tend not to be particularly large in project sum, it was noticed early on the advantages of introducing private expertise to deal with tasks that the public sector was probably not as efficient or experienced in carrying out the works. Despite a long history of PPPs implementation, many jurisdictions are still unclear of how to maxi- 
mize the benefits to suit their culture, environment, background, geography etc. This paper therefore sets out to address the following important issues:

a. Identify the benefits, difficulties and critical success factors of PPP.

b. Measure the effectiveness of PPP against other procurement methods.

c. Identify representative case studies from countries such as Australia for analysis to identify their approach to success/failure.

d. Identify previous projects in Hong Kong that utilized a similar approach to PPP and to analyze their implementation successfulness.

e. Investigate the best conditions in terms of project nature, project complexity, project types and project scales under which the use of PPP is the most appropriate.

f. Evaluate the findings collected to determine a best practice framework for implementing PPP in Hong Kong.

\section{Literature Review}

\subsection{What is the traditional practice of procuring public works project?}

PPP projects are often compared with projects that are not procured by the PPP model i.e. traditional projects. But what exactly are traditional projects and how are they procured? Traditional projects unlike PPP projects do not involve the private sector in sharing the project risks. In traditional projects the public sector will undertake most risks. In a PPP arrangement the private sector will have to take up a certain proportion of the risks, often related to their duties i.e. construction, design, maintenance and operation. Whereas the public sector will take up some of the risks that are more difficult to control by the private sector alone such as environment and government approval risks. Another major difference, but not always, depending on the financial package of the project is that traditional projects are financed fully by the public sector whereas in a PPP project it is likely that the private consortium will have some equity in the asset being delivered. Again in a traditional arrangement the public sector undertakes the financial risk as well. For example in a toll road the public sector would need to undertake the revenue risk in a traditional project, whereas in a PPP project this risk would be undertaken most likely by the private sector. Therefore in general the main difference between a project procured traditionally and by PPP is the risk sharing matrix. Table 1 shows a general risk sharing matrix for the public and private sectors in PPP projects (Grimsey and Lewis 2004). Many other studies have also been carried out in this area ( $\mathrm{Li}$ et al. 2005; Sun et al. 2008; Thomas et al. 2003, 2006; Wibowo and Kochendörfer 2005; $\mathrm{Ng}$ and Loosemore 2007; Lam et al. 2007).

\subsection{PPP experience in Hong Kong}

Hong Kong is not completely new to the idea of PPP. In actual fact the city was probably one of the first to utilize resources from the private sector. The term PPP may sound revolutionary to Hong Kong, whereas a more familiar term is Build Operate Transfer (BOT). The concept of BOT has been used since the late sixties. In September 1969 the construction for the first BOT project in Hong Kong commenced (Mak and Mo 2005). The Cross Harbour Tunnel (CHT) is a two lane tunnel in each direction. It took only 36 months to complete and was eleven months ahead of schedule. The CHT was an instant success when it came into operation in August 1972. Within three and a half years of operation the Tunnel had collected enough tolls to pay back its construction cost. The Tunnel is probably the most successful BOT project in Hong Kong, and is still one of the most important and profitable pieces of infrastructure locally (Asian Development Bank 2000).

Although Hong Kong has had experience in adopting quite a number of BOT projects, the approach of PPP has never really been studied extensively in the local context. The traditional practice of these projects was for the government to directly award a concession to the potential bidder. This practice of awarding concessions is common in Hong Kong, but the gestation period spent in formulating the enabling legislation is lengthy (Zhang 2001).

In recent years the Efficiency Unit of the Hong Kong Special Administrative Region (HKSAR) Government has been heavily involved in PPP research. The Government's interest in utilizing PPP is obvious. The approaches that they have taken mainly involve gaining international experience from particularly Europe and Australia. One of the early documents produced by the Efficiency Unit on private sector involvement was a guideline to help governmental bureaus and departments to familiarize with private sector engagement (Efficiency Unit 2001). These guidelines were published in 2001 and showed the government's interest in adopting the idea of PPP. Only two years later they also produced a comprehensive introductory guide to PPP (Efficiency Unit 2003). This guide was aimed for the use of the civil service but is also made available for the public's interest to understand the government's approach. After the publication of this report much interest was drawn from the public due to the possibility of the increased business opportunities available. More recently, the Efficiency Unit published two more guidelines on PPP (Efficiency Unit 2007, 2008a). The first of these publications shows how more knowledge on the issues of PPP have been learnt, it also identifies areas of concern to local practitioners as well as civil servants, and it tries to provide some insights into these areas. The second publication is much more specific on how to establish a PPP project. The guideline is aimed at coaching civil servants on how to conduct a PPP project by looking at the business case, dealing with the private sector, managing the risks, funding and payment issues, managing performance etc. 
Table 1. A general risk sharing matrix for the public and private sectors in PPP projects (Grimsey and Lewis 2004)

\begin{tabular}{|c|c|c|}
\hline Type of risk & Source of risk & Risk taken by \\
\hline \multicolumn{3}{|l|}{ Site risks } \\
\hline Site conditions & Ground conditions, supporting structures & Construction contractor \\
\hline \multirow[t]{2}{*}{ Site preparation } & $\begin{array}{l}\text { Site redemption, tenure, pollution/discharge, } \\
\text { obtaining permits, community liaison }\end{array}$ & Operating company/project company \\
\hline & Pre-existing liability & Government \\
\hline Land use & Native title, cultural heritage & Government \\
\hline \multirow{2}{*}{ Technical risks } & Fault in tender specifications & Government \\
\hline & Contractor design fault & Design contractor \\
\hline \multicolumn{3}{|l|}{ Construction risks } \\
\hline \multirow[t]{2}{*}{ Cost overrun } & $\begin{array}{l}\text { Inefficient work practices and wastage of materi- } \\
\text { als }\end{array}$ & Construction contractor \\
\hline & Changes in law, delays in approval, etc. & Project company/investors \\
\hline \multirow[t]{2}{*}{ Delay in completion } & $\begin{array}{l}\text { Lack of coordination of contractors, Failure to } \\
\text { obtain standard planning approvals }\end{array}$ & Construction contractor \\
\hline & Insured force majeure events & Insurer \\
\hline $\begin{array}{l}\text { Failure to meet performance crite- } \\
\text { ria }\end{array}$ & $\begin{array}{l}\text { Quality shortfall/defects in construc- } \\
\text { tion/commissioning tests failure }\end{array}$ & $\begin{array}{l}\text { Construction contractor/project com- } \\
\text { pany }\end{array}$ \\
\hline \multicolumn{3}{|l|}{ Operating risks } \\
\hline \multirow{3}{*}{ Operating cost overrun } & Project company request or change in practice & Project company/investors \\
\hline & $\begin{array}{l}\text { Industrial relations, repairs occupational health } \\
\text { and safety, maintenance, other costs }\end{array}$ & Operator \\
\hline & Government change to output specifications & Government \\
\hline \multirow[b]{2}{*}{ Delays or interruption in operation } & Operator fault & Operator \\
\hline & $\begin{array}{l}\text { Government delays in granting or renewing } \\
\text { approvals providing contracted inputs }\end{array}$ & Government \\
\hline \multirow{2}{*}{ Shortfall in service quality } & Operator fault & Operator \\
\hline & Project company fault & Project company/investors \\
\hline \multicolumn{3}{|l|}{ Revenue risks } \\
\hline \multirow{3}{*}{ Increase in input prices } & $\begin{array}{l}\text { Contractual violations by government-owned } \\
\text { support network }\end{array}$ & Government \\
\hline & Contractual violations by private supplier & Private supplier \\
\hline & Other & Project company/investors \\
\hline Changes in taxes, tariffs & Fall in revenue & Project company/investors \\
\hline Demand for output & Decreased demand & Project company/investors \\
\hline \multicolumn{3}{|l|}{ Financial risks } \\
\hline Interest rates & Fluctuations with insufficient hedging & Project company/government \\
\hline Inflation & Payments eroded by inflation & Project company/government \\
\hline Force majeure risk & Floods, earthquakes, riots, strikes & Shared \\
\hline \multicolumn{3}{|l|}{ Regulatory/political risks } \\
\hline \multirow[b]{2}{*}{ Changes in law } & Construction period & Construction contractor \\
\hline & Operating period & $\begin{array}{l}\text { Project company, with government } \\
\text { compensation as per contract }\end{array}$ \\
\hline \multirow{3}{*}{ Political interference } & Breach/cancellation of license & Government \\
\hline & Expropriation & Insurer, project company/investor \\
\hline & $\begin{array}{l}\text { Failure to renew approvals discriminatory taxes, } \\
\text { import restrictions }\end{array}$ & Government \\
\hline \multirow[t]{2}{*}{ Project default risks } & Combination of risks & $\begin{array}{l}\text { Equity investors followed by banks, } \\
\text { bondholders and institutional lenders }\end{array}$ \\
\hline & Sponsor suitability risk & Government \\
\hline \multirow{3}{*}{ Asset risks } & Technical obsolescence & Project company \\
\hline & Termination & Project company/operator \\
\hline & Residual transfer value & Government \\
\hline
\end{tabular}




\subsection{PPP experience in Australia}

The practice for delivering public works projects across Australia is quite different depending on the state. Each state government will have its own set of guidelines and rules to go by. Political decisions are crucial in deciding procurement processes. PPP has been an increasingly popular choice for delivering public works projects in Australia. Although for decades there have been known to be public works projects delivered in Australia by similar partnership arrangements, it has only been since the early nineties that PPP was first properly introduced in Australia. PPP has been a growing alternative to procuring public projects across the world. Especially with the success seen from the Victoria state, the other Australian states are eager to get a taste (Ernst and Young 2006).

The Victoria government released the Partnerships Victoria policy in June 2000 providing a framework for developing contractual partnerships between the public and the private sector for public infrastructure and services (Partnerships Victoria 2000). This bought about the change to the traditional practice of using Build Own Operate (BOO) and Build Own Operate Transfer (BOOT). The traditional practice focused more on bringing in the private sector's financial input and also having the risk transferred from the public sector to the private sector. But since the Partnerships Victoria policy the focus moved more towards delivering better projects as a result of bringing in the private sector expertise and also the government would regain direct control over the service or facility after the concession period.

The Partnerships Victoria team is part of the Commercial Division in the Department of Treasury and Finance of the Victoria state. The team is mainly responsible for overseeing projects implemented via the PPP practice and also developing guidelines and policies for PPP projects. Up to present, seventeen projects have already been implemented under Partnerships Victoria totaling AUD\$5.5 billion (Partnerships Victoria 2008a). The team has also produced four policies, four guidelines, three technical notes and four advisory notes for the implementation of PPP projects in Victoria. These publications are targeted for the use of both the private and public sectors, and cover areas including the public sector comparator, risk allocation, standard commercial principles, tender process, interest rates etc. (Partnerships Victoria 2008b).

\subsection{PPP experience in the United Kingdom}

PPP projects now account for about 15 and 8 percent of infrastructure spent in the United Kingdom and Australia respectively (Ernst and Young 2005). Up to 2006, 794 PPP/PFI deals had already been signed. The combined capital value was approximately $£ 55$ billion (National Audit Office, 2008). Amongst these projects almost 70\% were in the health sector, and over $40 \%$ costing below $£ 10$ million (Akintoye 2007). However, Maltby (2003) asserted that PPP/PFI should be abolished for smaller projects and for information technology schemes.
Partnership UK was set up in 2000 to succeed the Treasury Taskforce. The Taskforce was set up in 1997 to oversee the implementation of PPP/PFI projects. One observation is that Partnerships UK was initiated by the local Treasury. The team is generally responsible for providing project advice and support, developing government policies, providing co-sponsorship and participating in investment of PPP/PFI projects.

Due to the long history of PPP/PFI projects in the United Kingdom, Partnerships UK has a very comprehensive collection of guidelines and policies on implementing PPP projects for all sectors in many aspects. Case study reports can also be found on the public domain. Amongst the projects conducted by Partnerships UK it was noticed that the majority included projects for schools, hospitals and transportation. Other projects which have also been conducted include environment ones, leisure facilities, prisons and detention centers, housing etc. (Partnerships UK 2008). The extent to which PFI could be used and the advantages created were the main drivers attracting other countries to start adopting or improve their practice in PPP.

\section{The Research Framework}

The findings presented in this paper are part of an ongoing research project looking at developing a best practice framework for implementing PPPs. As part of the data collection, interviews were conducted with PPP experts that represented the public sector in both Hong Kong and Australia. This paper did not aim to provide a general overview of PPP in Hong Kong or Australia but instead tried to draw some commonalities and differences observed between the two jurisdictions.

\subsection{Design of Interview Questions}

The interviews which were carried out in this research study adopted the "Grounded Theory" approach. This approach is an iterative process by which the analyst becomes more and more "grounded" in the data and develops increasingly richer concepts and models of how the phenomenon being studied really works (Denzin and Lincoln 2007). This approach involves the interviewer to collect word for word transcripts from the interviewees. These transcripts can then be further analyzed by identifying themes which are common and meaningful by an "open coding" technique. Therefore the findings will be solely based on the responses given by the interviewees.

Dainty et al. (2000) also adopted the Grounded Theory approach for construction management research. In their methodology they collected unstructured data and coded meaning information. This method allows the researcher to relate categories in complex ways and ensuring density and precision to the developed theory. They also believed that too much structuring would mean that the interviewees' responses would be defined by the researcher. Hence, they used a semi-structured interview format. Their aim was not to promote consistency in terms of response, but to uncover as many relevant res- 
ponses as possible. Consistencies would therefore emerge from the subsequent Grounded Theory analysis.

Raiden et al. (2008) agreed that structured questions would not allow interviewees to fully expand on their knowledge. This does not mean that the theory from literature should not be tested but its generalization should be tested with a population first.

Based on these concepts, interviews were conducted with experts from the public sector. The experts were selected based on two main criteria, these included:

1) The experts must possess adequate knowledge in the area of PPP; and

2) The experts have hands-on experience with PPP projects, or experience in conducting PPP research or have followed very closely with the development of PPP.

Based on the Grounded Theory approach, six interview questions linking up to the project objectives were derived for the interviews with the public sector interviewees. Table 2 shows how these objectives are linked to the interview questions. In the first question the interviewees were asked "Have you conducted any research looking at local case studies?" This question aimed to collect information for objectives 3-6. Question 2 "How would you compare PPP with traditional procurement methods?" targeted to achieve objectives 2, 4-6. Objectives 5-6 were covered again in Question 3 "Which type of project do you feel is best suited to use PPP?" and Question 4 "What do you feel are the key performance indicators in a PPP project?" In Question 5, interviewees were asked to answer "In general, what do you think are the critical success factors leading to successful PPP projects?" This question sought information for objectives 1 , and 6. The final question was "Does your organization have any in-house guidance/practice notes?" This question aimed to collect information for objectives 1, 5-6.

\subsection{Selecting Respondents}

The target respondents of the interviews were practitioners with experience in PPP of senior level and authority who have had experience representing the public sector. A total of fourteen interviews were conducted, with seven interviews conducted in each jurisdiction. Amongst the seven interviews conducted in Hong Kong, two were from Administration Departments (one of the interviewees previously represented a Works Department), three were from Works Departments (one of which previously represented an Administration Department and the other also holds a position at a local institute), two of the interviewees were from Non Governmental Organizations (NGO) (both had previously acted for different Works Departments). The Australian interviewees consisted of three government officials and four specialist advisers from the private sector. The government officials interviewed are from local state education and treasury departments. When arranging the interviews in Australia, it was found that the state governments tended to employ advisers from the private sector to act on their behalf in providing advice and expertise for selecting and monitoring the PPP project consortia. Therefore four advisers from the private sector were also selected for interview. Their roles were solely on behalf of the public sector hence their responses can also be regarded as the public sector's view. Background details of these experts are shown in Tables 3 and 4 for Hong Kong and Australian interviewees respectively.

\section{A Comparison of the public sector's perspective in Hong Kong and Australia}

Table 5 shows a summary of the responses to each question given by the fourteen interviewees. The number of times that each response was given was tallied. Where the response was only given once it was believed to be insignificant for further analysis. For the responses given more than once, these were tabulated and further analyzed as shown in Tables 6 to 11. The numbers in brackets represents the number of times the response was mentioned by interviewees.

\subsection{Research on local case studies}

Table 6 shows the responses of Question 1 "Have you conducted any research looking at local case studies?" that were given more than once. The findings show that three different responses were given by Hong Kong interviewees and four were given by the Australians. Amongst the four responses given by the Australian interviewees, three were the same as those given by the Hong Kong interviewees. The response which was given most by both groups of interviewees was "Other research conducted", mentioned five times for each. This finding showed that irrespective of geographical locations the interviewees tended to conduct other research besides case studies on PPP. The response "Local case studies" was mentioned four times by the Australians. It is possible that because Australia has had much experience in conducting PPP projects, they do not need to look else where to learn from the experience of others, instead they can refer to their own projects as reference material. As mentioned previously the Victoria state in Australia for example has a large range of guidance materials on the public domain which other states can refer to when conducting PPP projects (Partnerships Victoria 2008b). On the other hand the Hong Kong interviewees mentioned "International case studies" three times showing there need to learn from the experience of others. The Efficiency Unit of the HKSAR Government has also been known to be interested in international case studies. They have also published a number of case study reports for PPP projects in the United Kingdom and Australia (Efficiency Unit 2008b). The Australians also mentioned this response two times. From the interviews it was found that the involvement in research was "Not mentioned" twice by each group of interviewees.

\subsection{Comparing PPP with traditional procurement methods}

Table 7 shows the responses mentioned more than once by both groups of interviewees for Question 2 "How would you compare PPP with traditional procurement 


\begin{tabular}{|c|c|c|c|c|c|c|}
\hline \multirow[b]{3}{*}{ Question } & \multicolumn{6}{|c|}{ Objective } \\
\hline & 1 & 2 & 3 & 4 & 5 & 6 \\
\hline & $\begin{array}{l}\text { Identify the } \\
\text { benefits, difficul- } \\
\text { ties and critical } \\
\text { success factors } \\
\text { of PPP }\end{array}$ & $\begin{array}{l}\text { Measure the } \\
\text { effectiveness of } \\
\text { PPP against } \\
\text { other procure- } \\
\text { ment methods }\end{array}$ & $\begin{array}{l}\text { Identify represen- } \\
\text { tative case studies } \\
\text { from countries } \\
\text { such as Australia } \\
\text { for analysis to } \\
\text { identify their } \\
\text { approach to } \\
\text { success/failure }\end{array}$ & $\begin{array}{l}\text { Identify previous } \\
\text { projects in Hong } \\
\text { Kong that utilized } \\
\text { a similar approach } \\
\text { to PPP and to } \\
\text { analyze their } \\
\text { implementation } \\
\text { successfulness }\end{array}$ & $\begin{array}{l}\text { Investigate the best } \\
\text { conditions in terms of } \\
\text { project nature, project } \\
\text { complexity, project } \\
\text { types and project } \\
\text { scales under which the } \\
\text { use of PPP is the most } \\
\text { appropriate }\end{array}$ & $\begin{array}{l}\text { Evaluate the } \\
\text { findings collected } \\
\text { to determine a } \\
\text { best practice } \\
\text { framework for } \\
\text { implementing PPP } \\
\text { in Hong Kong }\end{array}$ \\
\hline 1. Have you conducted any research looking at local case studies? & & & $\checkmark$ & $\checkmark$ & $\checkmark$ & $\checkmark$ \\
\hline $\begin{array}{l}\text { 2. How would you compare PPP with traditional procurement } \\
\text { methods? }\end{array}$ & & $\checkmark$ & & $\checkmark$ & $\checkmark$ & $\checkmark$ \\
\hline 3. Which type of project do you feel is best suited to use PPP? & & & & & $\checkmark$ & $\checkmark$ \\
\hline $\begin{array}{l}\text { 4. What do you feel are the key performance indicators in a PPP } \\
\text { project? }\end{array}$ & & & & & $\checkmark$ & $\checkmark$ \\
\hline $\begin{array}{l}\text { 5. In general, what do you think are the critical success factors } \\
\text { leading to successful PPP projects? }\end{array}$ & $\checkmark$ & & & & & $\checkmark$ \\
\hline $\begin{array}{l}\text { 6. Does your organization have any in-house guidance/practice } \\
\text { notes? }\end{array}$ & $\checkmark$ & & & & $\checkmark$ & $\checkmark$ \\
\hline
\end{tabular}

Table 3. List of Interviewees from the Public sector in Hong Kong

\begin{tabular}{c|l|l}
\hline No. & Position of Interviewee & \multicolumn{1}{c}{ Organization of Interviewee } \\
\hline PU1 & Assistant Director & Administration Department \\
\hline PU2 & Permanent Secretary & $\begin{array}{l}\text { Administration Department } \\
\text { (previously Works Department) }\end{array}$ \\
\hline PU3 & Director & $\begin{array}{l}\text { Works Department } \\
\text { (previously Administration Department) }\end{array}$ \\
\hline PU4 & Senior Director & Works Department \\
\hline PU5 & Senior Quantity Surveyor & Works Department / Local Professional Institute \\
\hline PU6 & Executive Board Member & NGO (previously Works Department) \\
\hline PU7 & Executive Director & NGO (previously Works Department) \\
\hline
\end{tabular}

Table 4. List of Interviewees from the Public sector in Australia

\begin{tabular}{c|l|l}
\hline No. & \multicolumn{1}{|c|}{ Position of Interviewee } & \multicolumn{1}{c}{ Organization of Interviewee } \\
\hline PU8 & Executive Director & Education Department \\
\hline PU9 & Director & Treasury Department \\
\hline PU10 & Executive Manager & Treasury Department \\
\hline PU11 & Executive Director & Transaction Adviser \\
\hline PU12 & Partner & Legal Adviser \\
\hline PU13 & Head & Finance Adviser \\
\hline PU14 & Director & Finance Adviser \\
\hline
\end{tabular}




\begin{tabular}{|c|c|c|c|c|c|c|c|c|c|c|c|c|c|c|c|c|}
\hline & \multicolumn{8}{|c|}{ Hong Kong Interviewees } & \multicolumn{8}{|c|}{ Australian Interviewees } \\
\hline & PU1 & PU2 & PU3 & PU4 & PU5 & PU6 & PU7 & Total & PU8 & PU9 & PU10 & PU11 & PU12 & PU13 & PU14 & Total \\
\hline \multicolumn{17}{|c|}{ 1. Have you conducted any research looking at local case studies? And if so, could you share your insights? } \\
\hline Local case studies & $\checkmark$ & & & & & & & 1 & & $\checkmark$ & $\checkmark$ & & & $\checkmark$ & $\checkmark$ & 4 \\
\hline International case studies & $\checkmark$ & $\checkmark$ & $\checkmark$ & & & & & 3 & & & & & & $\checkmark$ & $\checkmark$ & 2 \\
\hline Other research conducted & $\checkmark$ & $\checkmark$ & $\checkmark$ & $\checkmark$ & $\checkmark$ & & & 5 & $\checkmark$ & $\checkmark$ & $\checkmark$ & & & $\checkmark$ & $\checkmark$ & 5 \\
\hline Not mentioned & & & & & & $\checkmark$ & $\checkmark$ & 2 & & & & $\checkmark$ & $\checkmark$ & & & 2 \\
\hline \multicolumn{17}{|c|}{ 2. How would you compare PPP with traditional procurement methods? } \\
\hline Using a Public Sector Comparator & $\checkmark$ & $\checkmark$ & & & & & & 2 & & & & & & & & $\mathbf{0}$ \\
\hline Longer tendering/negotiation for PPP & $\checkmark$ & & & & & & & 1 & $\checkmark$ & & & & & & & 1 \\
\hline Government act as supervisor in PPP & & $\checkmark$ & & & & & & 1 & & & & & & & & $\mathbf{0}$ \\
\hline Traditional method accepted as norm & & & $\checkmark$ & & & & & 1 & & & & & & & & $\mathbf{0}$ \\
\hline Each project unique & & & $\checkmark$ & & & $\checkmark$ & & 2 & & & & & & & & $\mathbf{0}$ \\
\hline Difference in payment mechanism & & & & $\checkmark$ & & & & 1 & & & & & & & & $\mathbf{0}$ \\
\hline $\begin{array}{l}\text { PPPs gain private sector's added efficien- } \\
\text { cy/expertise/management skills }\end{array}$ & & & & $\checkmark$ & & $\checkmark$ & & 2 & & & & $\checkmark$ & & & $\checkmark$ & 2 \\
\hline PPP projects delivered faster & & & & & $\checkmark$ & & & 1 & & & & & & & & $\mathbf{0}$ \\
\hline $\begin{array}{l}\text { PPP utilizes private sector finan- } \\
\text { ce/difference in finance structure }\end{array}$ & & & & & & $\checkmark$ & & 1 & $\checkmark$ & & $\checkmark$ & $\checkmark$ & & $\checkmark$ & & 4 \\
\hline PPP tend to be large project sums & & & & & & $\checkmark$ & & 1 & & & & & & & & $\mathbf{0}$ \\
\hline Difference in risk profile & & & & & & & & $\mathbf{0}$ & $\checkmark$ & & & & & & & 1 \\
\hline Operational differences & & & & & & & & $\mathbf{0}$ & $\checkmark$ & & & & & & & 1 \\
\hline Management differences & & & & & & & & $\mathbf{0}$ & $\checkmark$ & & & & & & & 1 \\
\hline PPPs have a more transparent process & & & & & & & & $\mathbf{0}$ & & $\checkmark$ & & & & & & 1 \\
\hline PPPs consider whole life cycle cost & & & & & & & & $\mathbf{0}$ & & & $\checkmark$ & & & & & 1 \\
\hline More parties involved in PPPs & & & & & & & & $\mathbf{0}$ & & & & & $\checkmark$ & & & 1 \\
\hline \multicolumn{17}{|c|}{ 3. Which type of project do you feel is best suited to use PPP? } \\
\hline Link between performance and payment & $\checkmark$ & & & & & & & 1 & & & & & & & & $\mathbf{0}$ \\
\hline Each project unique & & $\checkmark$ & & & & & & 1 & & & & & & & & $\mathbf{0}$ \\
\hline Economic business case & & & $\checkmark$ & & $\checkmark$ & $\checkmark$ & & 3 & & $\checkmark$ & & & & $\checkmark$ & $\checkmark$ & 3 \\
\hline Value for Money & & & $\checkmark$ & & & & & 1 & & & & & & & & $\mathbf{0}$ \\
\hline Large operating element/cost & & & & $\checkmark$ & & $\checkmark$ & & 2 & & & & & & & & $\mathbf{0}$ \\
\hline Performance easily measured & & & & $\checkmark$ & & & & 1 & & $\checkmark$ & & & & & $\checkmark$ & 2 \\
\hline Mutual benefits for all parties & & & & & & & $\checkmark$ & 1 & & & & & & & & $\mathbf{0}$ \\
\hline Economic infrastructure & & & & & & & & $\mathbf{0}$ & $\checkmark$ & & & & & & & 1 \\
\hline Scope for innovation & & & & & & & & $\mathbf{0}$ & & $\checkmark$ & & & & $\checkmark$ & $\checkmark$ & 3 \\
\hline High project costs & & & & & & & & $\mathbf{0}$ & & $\checkmark$ & $\checkmark$ & & & & & 2 \\
\hline Any nature & & & & & & & & $\mathbf{0}$ & & & & $\checkmark$ & $\checkmark$ & & & 2 \\
\hline Sufficient risk transfer & & & & & & & & $\mathbf{0}$ & & & & & & $\checkmark$ & $\checkmark$ & 2 \\
\hline
\end{tabular}


Continue of Table 5

4. What do you feel are the key performance indicators in a PPP project?

Project performance

Resources saved

Contractor's performance

Traditional KPIs: Cost, time, quality

Risk Management

Public acceptance

Value for money achieved

Service outcomes

Contract terms

Client satisfaction

Payment mechanism performed

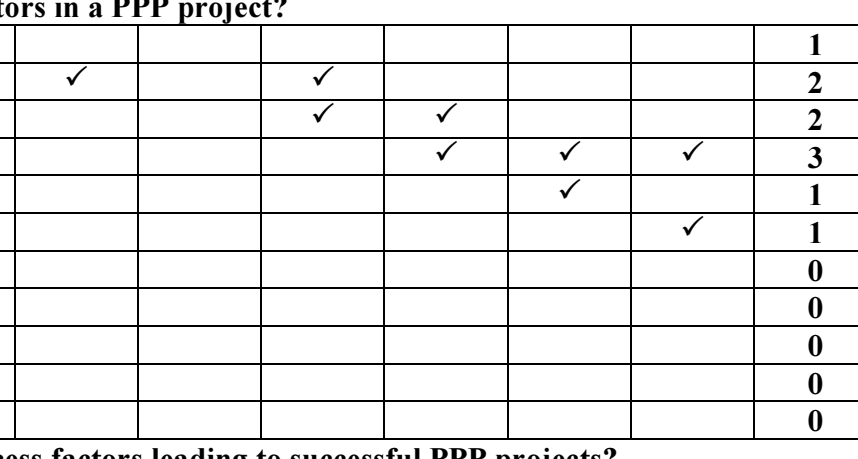

\begin{tabular}{|l|l|}
\hline$\checkmark$ & $\checkmark$ \\
\hline & \\
\hline$\checkmark$ & \\
\hline$\checkmark$ & \\
\hline & $\checkmark$ \\
\hline & \\
\hline & \\
\hline & \\
\hline & \\
\hline
\end{tabular}

\begin{tabular}{|l|l|l|l|} 
& & & \\
\hline & & $\checkmark$ & \\
\hline & & & \\
\hline & & & \\
\hline & & & \\
\hline & $\checkmark$ & $\checkmark$ & $\checkmark$ \\
\hline & & $\checkmark$ & \\
\hline & & & $\checkmark$
\end{tabular}

\begin{tabular}{l|l|l} 
& & $\mathbf{2}$ \\
\hline & & $\mathbf{0}$ \\
\hline & & $\mathbf{1}$ \\
\hline & & $\mathbf{2}$ \\
\hline & & $\mathbf{1}$ \\
\hline & $\checkmark$ & $\mathbf{4}$ \\
\hline & $\mathbf{1}$ \\
\hline & & $\mathbf{1}$ \\
\hline
\end{tabular}

5. In general, what do you think are the critical success factors leading to successful PPP projects?

Champion

Large project capital value

Well prepared contract/document

Partnership spirit/commitment/trust

Transparent process

Project objectives well defined

Public consultation

Appropriate risk allocation

Large operating element

Development potential

Economic business case

Effective negotiations between parties

Competitive procurement process

Government support

Skilled and experienced parties

Clear milestones

Initiate project

Value for money

\begin{tabular}{|l|l|l|l|l|l|l|} 
& & & & & & \\
\hline$\checkmark$ & & & $\checkmark$ & & & \\
\hline$\checkmark$ & & & & & $\checkmark$ & \\
\hline$\checkmark$ & & & & & $\checkmark$ & \\
\hline$\checkmark$ & & & $\checkmark$ & & $\checkmark$ & \\
\hline & & & $\checkmark$ & $\checkmark$ & & \\
& & $\checkmark$ & & & & \\
& & & $\checkmark$ & & & \\
& & & & $\checkmark$ & & \\
& & & & & & \\
& & & & & & \\
\hline & & & & & & \\
\hline & & & & & & \\
\hline & & & & & & \\
\hline
\end{tabular}

\begin{tabular}{|c|c|c|c|c|c|c|c}
\hline & $\checkmark$ & $\checkmark$ & & & & $\checkmark$ & $\mathbf{3}$ \\
\hline & & & & & & & $\mathbf{0}$ \\
\hline$\checkmark$ & & & & & & $\checkmark$ & $\mathbf{1}$ \\
\hline & & & & & & $\checkmark$ & $\mathbf{2}$ \\
\hline & & $\checkmark$ & & & & & $\mathbf{3}$ \\
\hline & & & $\checkmark$ & & & & $\mathbf{1}$ \\
\hline & & & & & & & $\mathbf{0}$ \\
\hline & & & & & & & $\mathbf{0}$ \\
\hline & & & $\checkmark$ & & $\checkmark$ & & $\mathbf{2}$ \\
\hline & $\checkmark$ & & & & & & $\mathbf{1}$ \\
\hline & $\checkmark$ & $\checkmark$ & $\checkmark$ & $\checkmark$ & & & $\mathbf{5}$ \\
\hline & $\checkmark$ & $\checkmark$ & $\checkmark$ & & & & $\mathbf{3}$ \\
\hline & & & $\checkmark$ & & & & $\mathbf{1}$ \\
\hline & & & $\checkmark$ & & & $\checkmark$ & $\mathbf{2}$ \\
\hline
\end{tabular}

6. Does your organization have any in-house guidance/practice notes?

Yes

No

Refer to others

\begin{tabular}{l|l}
\hline & $\checkmark$ \\
\hline$\checkmark$ & $\checkmark$ \\
\hline
\end{tabular}

\begin{tabular}{l|l|l|l|l}
\hline & $\checkmark$ & & -1 \\
\hline$\checkmark$ & & \\
\hline & &
\end{tabular}

$\checkmark$

$\checkmark$

\begin{tabular}{|l|l|}
\hline & \\
\hline & \\
\hline
\end{tabular}

\begin{tabular}{|c|c|}
\hline$\checkmark$ & 6 \\
\hline & 0 \\
\hline . & 1 \\
\hline
\end{tabular}


methods?" Three and two different responses were mentioned more than once by the Hong Kong and Australian interviewees respectively. For all three responses mentioned by the Hong Kong interviewees each was mentioned twice. Mentioned the most by Australian interviewees was "PPP utilizes private sector finance/ difference in finance structure" which was mentioned four times. This finding shows the importance of the different financing structure provided by PPP projects. Although finance should not be the main reason for adopting PPP projects, undoubtedly, financial drive is still an attractive factor to governments, hence this response was unsurprising. Mentioned by both groups of interviewees was the response "PPPs gain private sector's added efficiency/expertise/management skills". This response was also mentioned twice by the Australian interviewees. From previous literature it has also been recorded that one of the main advantages of involving the private sector is to add value to public projects in terms of their efficiency, expertise and management skills when compared to those of the public sector (Yescombe 2007; Carrillo et al. 2008; Leiringer 2006; Chiang and Cheng 2009). Other response mentioned by the Hong Kong interviewees included "Using a Public Sector Comparator", which was also mentioned by the Efficiency Unit (2003) of the HKSAR government as necessary whenever public money is involved. Also "Each project unique" was mentioned the Hong Kong interviewees too.

\subsection{Projects best suited to use PPP}

The Interviewees were asked to answer "Which type of project do you feel is best suited to use PPP?" in Question 3. Table 8 shows their responses that were mentioned more than once. The results showed that only one similar response was mentioned by both groups of interviewees. This was "Economic business case" which was mentioned three times by both groups of interviewees and also mentioned the most. The private sector parties are businessmen, so for them to participate in PPP projects there must be reasonable financial benefits foreseeable for them. Partnerships Victoria (2001) explains how developing a business case is a key step in the decisionmaking process. This is where the project is fully scoped and risks and costs are identified to develop a cost-benefit analysis, as well as to test the net benefit of the proposal. The Hong Kong interviewees suggested only one more criteria for PPP projects, which was "Large operating element/cost" which was mentioned twice. One typical feature of PPP projects is that the consortium is normally responsible for the operation and maintenance of the project. Without this element PPP projects would be similar to projects procured traditionally. Therefore the operation part must constitute a reasonable proportion of the project. Grimsey and Lewis (2004) listed a number of public private business models prior to the more general term PPP, many of these emphasized the operation element of the structure within its name, showing the highly important role in these arrangements including: Operate and Maintain (O\&M); Operate Maintain and Manage (OM\&M); Build Transfer Operate (BTO); Build Operate Transfer (BOT); Build Own Operate Remove (BOOR); Build Own Operate Transfer (BOOT); Lease Renovate Operate Transfer (LROT); Design Build Finance Operate (DBFO); Design Build Finance Operate Manage (DBFOM); Build Own Operate (BOO) etc. Other response given by the Australian interviewees included "Scope for innovation" (Eaton et al. 2006) which was mentioned

Table 6. Question 1 - Have you conducted any research looking at local case studies?

\begin{tabular}{|l|l|l|}
\hline \multicolumn{1}{|c|}{ Hong Kong Interviewees } & \multicolumn{1}{c|}{ Australian Interviewees } \\
\hline Other research conducted (5) & & Other research conducted (5) \\
\hline International case studies (3) & & Local case studies (4) \\
\hline Not mentioned (2) & & International case studies (2) \\
\hline
\end{tabular}

Table 7. Question 2 - How would you compare PPP with traditional procurement methods?

\begin{tabular}{|l|l|}
\hline \multicolumn{1}{|c|}{ Hong Kong Interviewees } & \multicolumn{1}{c|}{ Australian Interviewees } \\
\hline Using a Public Sector Comparator (2) & $\begin{array}{l}\text { PPP utilizes private sector fi- } \\
\text { nance/difference in finance structure (4) }\end{array}$ \\
\hline $\begin{array}{l}\text { PPPs gain private sector's added effi- } \\
\text { ciency/expertise/management skills (2) }\end{array}$ & $\begin{array}{l}\text { PPPs gain private sector's added effi- } \\
\text { ciency/expertise/management skills (2) }\end{array}$ \\
\hline Each project unique (2) & \\
\hline
\end{tabular}

Table 8. Question 3 - Which type of project do you feel is best suited to use PPP?

\begin{tabular}{|l|l|l|}
\hline \multicolumn{1}{|c|}{ Hong Kong Interviewees } & \multicolumn{1}{c|}{ Australian Interviewees } \\
\hline Economic business case (3) & \multicolumn{1}{|c|}{ Economic business case (3) } \\
\hline Large operating element/cost (2) & & Scope for innovation (3) \\
\hline & & Performance easily measured (2) \\
\hline & & High project value (2) \\
\hline & & Any nature (2) \\
\hline & & Sufficient risk transfer (2) \\
\hline &
\end{tabular}


three times. Also, mentioned twice each by the Australians included "Performance easily measured" (Partnerships Victoria 2001), "High project value" (HM Treasury 2003) "Any nature" and "Sufficient risk transfer" (Jin and Doloi 2008). These features forming suitable PPP projects have been previously recorded by other researchers.

\subsection{Key performance indicators in PPP projects}

The interviewees were also asked to answer Question 4 "What do you feel are the key performance indicators in a PPP project?" (Table 9). Amongst the responses received, three were mentioned more than once by the Hong Kong interviewees and four by the Australian interviewees. The response "Contract terms" was mentioned the most at four times by the Australian interviewees. In Australia high priority is given to the contract component of projects procured by PPP. Guidelines have also been published on this aspect (Partnerships Victoria 2008c). The response mentioned the most by Hong Kong interviewees was "Traditional KPIs: Cost, time, quality" (Enshassi et al. 2009). Probably due to the lack of experience in PPP projects (not including BOT type projects), the Hong Kong interviewees did not commonly come up with any responses that were specifically related to PPP projects solely. Only one response was raised by both groups of interviewees, this was "Contractor's performance" which was mentioned twice by each group of the interviewees. Also mentioned twice by the Australian interviewees were the responses "Project performance" and "Risk Management". The performance of the contractor and project are items which would definitely be mentioned in the contract documents, these again confirm the importance of the contract to the Australian interviewees. Many studies have been conducted on the importance of risks in PPP projects (Akbiyikli and Eaton 2004; Li et al. 2004, 2005; Shen and Wu 2005; Roumboutsos and Anagnostopoulos 2008). One of the main reasons for implementing public projects by PPP is also for risk transfer, therefore to classify the risk management as a perform- ance indicator is also reasonable. Another response mentioned by Hong Kong interviewees was "Resources saved". PPP projects are normally only conducted after they have been proved to be a cheaper alternative to traditionally procured projects. This is normally conducted via the Public Sector Comparator (Efficiency Unit 2003; Partnerships Victoria 2008b).

\subsection{Critical success factors leading to successful PPP projects}

Question 5 "In general, what do you think are the critical success factors leading to successful PPP projects?" received the most variation of responses from the interviewees (Table 10). This probably indicated that there are many ways for PPP projects to achieve success. For responses that were mentioned more than once, there were six from the Hong Kong interviewees and nine for the Australian interviewees. Amongst these only two were similar for both groups of interviewees, these included "Project objectives well defined" which was mentioned three times by each group of respondents and "Partnership spirit/commitment/trust" mentioned twice by each group of interviewees. As mentioned by the Efficiency Unit (2008c) and the Queensland Government (2008) the objectives / output specification of a PPP project must be well defined. The importance of partnership spirit was also identified by Gunnigan and Eaton (2006). Mentioned the most frequently by Australian interviewees was "Competitive procurement process" (Jefferies et al. 2002) at five times, followed by "Skilled and experienced parties" (Drew 2005; Kumaraswamy and Anvuur 2008) at four times, "Champion" (Efficiency Unit 2008a) and "Clear milestones" (Civic Exchange et al. 2005) both three times and "Economic business case" (Chege 2001), "Government support" (Qiao et al. 2001) and "Value for money" (Heald, 2003) all twice. Mentioned the most by Hong Kong interviewees was "Appropriate risk allocation" (Li et al. 2005) at four times, "Public consultation" (Kanakoudis 2007) at three times and "Well prepared

Table 9. Question 4 - What do you feel are the key performance indicators in a PPP project?

\begin{tabular}{|c|c|}
\hline Hong Kong Interviewees & Australian Interviewees \\
\hline Traditional KPIs: Cost, time, quality (3) & Contract terms (4) \\
\hline Contractor's performance (2) & Contractor's performance (2) \\
\hline Resources saved (2) & Project performance (2) \\
\hline & Risk Management (2) \\
\hline
\end{tabular}

Table 10. Question 5 - In general, what do you think are the critical success factors leading to successful PPP projects?

\begin{tabular}{|l|l|l|}
\hline \multicolumn{1}{|c|}{ Hong Kong Interviewees } & \multicolumn{1}{c|}{ Australian Interviewees } \\
\hline Appropriate risk allocation (4) & & Competitive procurement process (5) \\
\hline Public consultation (3) & & Skilled and experienced parties (4) \\
\hline Project objectives well defined (3) & & Project objectives well defined (3) \\
\hline Well prepared contract/document (2) & & Champion (3) \\
\hline Transparent process (2) & & Clear milestones (3) \\
\hline Partnership spirit/commitment/trust (2) & & Partnership spirit/commitment/trust (2) \\
\hline & & Economic business case (2) \\
\hline & & Government support (2) \\
\hline & & Value for money (2) \\
\hline & \\
\hline
\end{tabular}


contract/document" (Partnerships Victoria 2008c) and "Transparent process" (United Nations Economic Commission for Europe 2004) both at two times. The majority of these critical success factors have also been summarized by (Aziz 2007).

\subsection{In-house guidance/practice notes}

For Question 6 "Does your organization have any in-house guidance/practice notes?" it was found that the majority of the interviewees (six out of seven) in Australia responded "Yes", whereas only three interviewees in Hong Kong agreed (Table 11). Four Hong Kong interviewees responded "No" and two responded "Refer to others". This finding has shown that the Australians were much more likely to have their own guidance materials, whereas for the Hong Kong interviewees the responses varied. Australia has implemented many more PPP projects compared to Hong Kong; hence they can also be regarded as much more experienced. The Victoria state in Australia alone has implemented seventeen projects under the Partnerships Victoria arrangement (Partnerships Victoria 2008a) as mentioned previously. On the other hand, not considering the previous projects conducted by BOT, Hong Kong has only completed a couple of PPP projects.

Table 11. Question 6 - Does your organization have any in-house guidance/practice notes?

\begin{tabular}{|l|l|}
\hline $\begin{array}{c}\text { Hong Kong } \\
\text { Interviewees }\end{array}$ \\
\hline No (4) \\
\hline Yes (3) \\
\hline Refer to others (2) \\
\hline
\end{tabular}

\section{Conclusions}

This paper has studied the public sector's perspective on procuring public works projects via findings from fourteen interviews conducted in Hong Kong and Australia. Government officials and advisers with experience in PPP projects and research were invited to answer six questions related to the implementation. The results found that interviewees from both jurisdictions had conducted some kind of research in the area and had looked at international cases. This finding has shown that governments in both jurisdictions have shown an interest in other sources of information besides real cases and also both are keen to learn from international experiences. Therefore other governments can also consider using a similar approach if they have not already done so. The results from this question enabled objectives 3-6 to be achieved. Both groups of interviewees also found that the main difference between PPP and traditional projects is that in a PPP project there is the added advantage of the private sector's efficiency/expertise/management skills involved. Therefore other governments could consider whether this added advantage is required from the private sector when they consider whether or not to opt for the PPP model in their public work projects. The interviewees from Hong Kong also suggested using the Public Sector Comparator as an indicator to determine the pref- erence between the methods. Other criteria recommended by the Australian interviewees were the private sector financing and finance structure of the project. Again these could be used as indications to which method to opt for. These findings helped to achieve objectives 2, 4-6. The interviewees were asked which projects would be suitable to use PPP; both groups suggested that it would be crucial for projects to be economically viable. Another important feature according to the Australian interviewees is scope for innovation. Objectives 5-6 were therefore achieved. It was suggested by both groups of interviewees that the contractor's performance would be the key performance indicator in a PPP project. The Hong Kong interviewees also suggested that the traditional key performance indicators such as cost, time and quality are also important. The Australian interviewees suggested that the contract terms should be considered. These findings are valuable for measuring the performance of a PPP project for both the public and private sectors. Again, objectives 5-6 were achieved. Common critical success factors mentioned by both groups of interviewees included the project objectives being well defined and a partnering spirit/commitment/trust. These factors should be considered by all parties before the project begins to ensure that they are achieved. The Hong Kong interviewees also felt strongly that an appropriate risk allocation would achieve success in the project. For the Australian interviewees a competitive procurement process was the most important success factor. Objectives 1 and 6 were therefore achieved from these findings. Lastly it was found that all the interviewees from Australia and some of the ones from Hong Kong had a practice of having their own organization guidance/practice notes. This practice is highly recommended and especially useful for individuals and companies that are inexperienced with the PPP practice. From these findings objectives 1, 5-6 were achieved again. From the findings of two completely different jurisdictions that have already implemented PPP, the industry at large will understand better which types of projects should be procured by PPP and how these can be delivered the most effectively. In addition, the findings presented in this paper have formed a comparative study looking at implementation of PPPs in Hong Kong and Australia.

\section{Acknowledgments}

The work described in this paper was fully supported by a grant from the Research Grants Council of the Hong Kong Special Administrative Region, China (RGC Project No. PolyU 5114/05E). Sincere thanks goes to those industrial practitioners, who have kindly participated in the interviews reported in this paper. Also, Queensland University of Technology is gratefully acknowledged for offering a QUT International Doctoral Scholarship to the first author of this paper for her PhD study.

This paper forms part of a PhD research study entitled "Developing a Best Practice Framework for Implementing Public Private Partnerships in Hong Kong", from which other deliverables have been produced with different objectives/scope but sharing common background and methodology. 


\section{References}

Akbiyikli, R. and Eaton, D. 2004. Risk management in PFI procurement: A holistic approach, in Proceedings of the 20th Annual Association of Researchers in Construction Management (ARCOM) Conference, Heriot-Watt University, Edinburgh, United Kingdom, 1-3 September 2004, 1269-1279.

Asian Development Bank [online]. 2000. Developing Best Practices for Promoting Private Sector Investment in Infrastructure Roads [cited 20 August 2008]. Available from Internet: <http://www.worldbank.org/html/fpd/transport/ roads/tr_docs/annex16.pdf $>$.

Akintoye, A. 2007. Developments in the UK public private partnerships: lessons for the new PPP ventures (keynote paper), in Proceedings of the 2007 International Conference on Concession Public / Infrastructural Projects (ICCPIP), Dalian University of Technology, China, 2426 August 2007.

Aziz, A. M. A. 2007. Successful delivery of public-private partnerships for infrastructure development, ASCE: Journal of Construction Engineering and Management 133(12): 918-931. doi:10.1061/(ASCE)0733-9364(2007)133:12(918)

Carrillo, P.; Robinson, H.; Foale, P.; Anumba, C.; Bouchlaghem, D. 2008. Participation, barriers and opportunities in PFI: The United Kingdom Experience, ASCE: Journal of Management in Engineering 24(3): 138-145. doi:10.1061/(ASCE)0742-597X(2008)24:3(138)

Chege, L. W. 2001. Private financing of construction projects and procurement systems: an integrated approach, in Proceedings of the CIB World Building Congress, April 2001, Wellington, New Zealand.

Chiang, Y. H. and Cheng, E. W. L. 2009. Perception of financial institutions toward financing PFI projects in Hong Kong, ASCE: Journal of Construction Engineering and Management 135(9): 833-840. doi:10.1061/(ASCE)0733-9364(2009)135:9(833)

Civic Exchange, APCO Asia Limited and Hawker Britton 2005. Getting PPP Right: Using West Kowloon Cultural District as a Case Study Hong Kong.

Dainty, A. R. J.; Bagilhole, B. M. and Neale, R. H. 2000. Computer aided analysis of qualitative data in construction management research, Building Research and Information 84(4): 26-33.

Denzin, N. K. and Lincoln, Y. S. 2007. Handbook of qualitative research. Second Edition, Sage Publications Inc.

Drew, J. 2005. Public private partnerships - opportunities and challenges, in Proceedings of the Conference on Public Private Partnerships - Opportunities and Challenges, 22 February 2005, Hong Kong.

Eaton, D.; Akbiyukli, R. and Dickinson, M. 2006. An evaluation of the stimulants and impediments to innovation within PFI/PPP projects, Construction Innovation 6: 6377.

Efficiency Unit 2001. Serving the Community by Using the Private Sector. Hong Kong Special Administrative Region Government, Hong Kong.

Efficiency Unit 2003. Serving the community by using the private sector - An introductory guide to public private partnerships (PPPS). Hong Kong Special Administrative Region Government, Hong Kong.

Efficiency Unit 2007. Serving the Community By Using the Private Sector Policy and Practice (Second Edition, Janu- ary 2007, Hong Kong Special Administrative Region Government, Hong Kong.

Efficiency Unit 2008a. Serving the Community By Using the Private Sector - An Introductory Guide to Public Private Partnerships (PPPS) (Second Edition), March 2008, The Hong Kong Special Administrative Region Government, Hong Kong.

Efficiency Unit [online]. 2008b. List of Case Studies [cited 28 July 2008]. Available from Internet: $<$ http://www.eu.gov.hk/english/case/case.html $>$.

Efficiency Unit 2008c. Serving the Community Through Successful Project Delivery, $\quad$ May 2008, The Hong Kong Special Administrative Region Government, Hong Kong.

Enshassi, A.; Mohamed, S. and Abushaban, S. 2009. Factor affecting the performance of construction projects in Gaza strip, Journal of Civil Engineering and Management 15(3): 269-280. doi:10.3846/1392-3730.2009.15.269-280

Ernst and Young 2006. Project Finance - Asia Pacific PPP Market, July 2006.

Ernst and Young 2005. Australian PPP survey - issues facing the Australian PPP market, November 2005.

Grimsey, D. and Lewis, M. K. 2004. Public private partnerships: The worldwide revolution in infrastructure provision and project finance. Edward Elgar.

Gunnigan, L. and Eaton, D. 2006. Addressing the challenges that are emerging in the continued increase in PPP use in the Republic of Ireland, in BEAR Conference, 10-13 April 2006.

Heald, D. 2003. Value for money tests and accounting treatment in PFI schemes, Accounting, Auditing and Accountability Journal 16(3): 342-371. doi:10.1108/09513570310482291

HM Treasury. 2003. PFI: Meeting the Investment Challenge, July 2003, The United Kingdom.

Jefferies, M.; Gameson, R. and Rowlinson, S. 2002. Critical success factors of the BOOT procurement system: reflection from the Stadium Australia case study, Engineering, Construction and Architectural Management 9(4): 35261. doi:10.1046/j.1365-232X.2002.00249.X

Jin, X. H. and Doloi, H. 2008. Interpreting risk allocation mechanism in public - private partnership projects: an empirical study in a transaction cost economics perspective, Construction Management and Economics 26: 707-721. doi:10.1080/01446190801998682

Kanakoudis, V.; Papotis, A.; Sanopoulos, A.; Gkoutzios, V. 2007. Crucial parameters for PPP projects successful planning and implementation, in Proc of 12th International Conference on Urban Planning, Regional Development and Information Society REAL CORP 007, Ed. by M. Schrenk, M.; V. V. Popovich; J. Benedikt, 20-23 May, 2007, Vienna, Austria, 167-184.

Kumaraswamy, M. M. and Anvuur, A. M. 2008. Selecting sustainable teams for PPP projects, Building and Environment 43: 999-1009. doi:10.1016/j.buildenv.2007.02.001

Lam, K. C.; Wang, D.; Lee, P. T. K. and Tsang, Y. T. 2007. Modeling risk allocation decision in construction contracts, International Journal of Project Management 25(5): 485-493. doi:10.1016/j.ijproman.2006.11.005

Leiringer, R. 2006. Technological Innovation in PPPs: Incentives, Oppourtunities and Actions, Construction Management and Economics 24: 301-308. doi:10.1080/01446190500435028

Li, B.; Akintoye, A.; Edwards, P. J. and Hardcastle, C. 2004. Risk treatment preferences for PPP/PFI construction pro- 
jects in the UK, in Proceedings: ARCOM Conference, Heriot Watt University, 1-3 September 2004, Vol. 2: 1259-1268.

Li, B.; Akintoye, A.; Edwards, P. J. and Hardcastle, C. 2005. The allocation of risk in PPP/PFI construction projects in the UK, International Journal of Project Management 23(1): 25-35. doi:10.1016/j.ijproman.2004.04.006

Mak, C. K. and Mo, S. 2005. Some aspects of the PPP approach to transport infrastructure development in Hong Kong, in Proceedings of the Conference on Public Private Partnerships - Opportunities and Challenges, Hong Kong, February $22,2005$.

Maltby, P. 2003. Has the PFI grown up? Public Finance, London, August 2003.

National Audit Office [online]. 2008. Background to Private Finance [cited 13 July 2008]. Available from Internet: $<$ http://www.nao.org.uk/practice_areas/private_finance/ba ckground.htm>.

Ng, A. and Loosemore, M. 2007. Risk allocation in the private provision of public infrastructure, International Journal of Project Management 25(1): 66-76. doi:10.1016/j.ijproman.2006.06.005

Partnerships UK [online]. 2000 [cited 25 June 2008]. Available from Internet: <www.partnershipsuk.org.uk>.

Partnerships Victoria 2000. Partnerships Victoria Policy, Department of Treasury and Finance, Victoria State Government, Australia.

Partnerships Victoria 2001. Practitioner's Guide, June 2001, Department of Treasury and Finance, Victoria State Government, Australia.

Partnerships Victoria [online]. 2008a. Projects [cited 24 July 2008]. Department of Treasury and Finance, Victoria State Government, Australia. Available from Internet: $<$ http://www.partnerships.vic.gov.au/CA25708500035EB 6/WebProjects?OpenView>.

Partnerships Victoria [online]. 2008b. Policy and Guidelines [cited 24 July 2008]. Department of Treasury and Finance, Victoria State Government, Australia. Available from Internet: $\quad<\mathrm{http}: / /$ www.partnerships.vic.gov.au/CA 25708500035EB6/0/C0005AB6099597C2CA2570F5000 6F3AA?OpenDocument>

Partnerships Victoria 2008c. Standard Commercial Principles, April 2008, Department of Treasury and Finance, Victoria State Government, Australia.

Qiao, L.; Wang, S. Q.; Tiong, R. L. K. and Chan, T. S. 2001. Framework for critical success factors of BOT projects in China, Journal of Project Finance 7(1): 53-61.
Queensland Government [online]. 2008. Business Case Development [cited 29 July 2008]. Available from Internet: $<$ http://www.dip.qld.gov.au/docs/library/pdf/ppp/ppp_ guide_bus_case_dev.pdf $>$.

Raiden, A. B.; Dainty, A. R. J. and Neale, R. H. 2008. Understanding employee resourcing in construction organizations, Construction Management and Economics 26(11): 1133-1143. doi:10.1080/01446190802422153

Roumboutsos, A. and Anagnostopoulos, K. P. 2008. Publicprivate partnership projects in Greece: risk ranking and preferred risk allocation, Construction Management and Economics 26: 751-763. doi:10.1080/01446190802140086

Shen, L. Y. and Wu, Y. Z. 2005. Risk concession model for BOT contract projects, Journal of Construction Engineering and Management, ASCE 131(2): 211-220. doi:10.1061/(ASCE)0733-9364(2005)131:2(211)

Sun, Y.; Fang, D. P.; Wang, S. Q.; Dai, M. D. and Lv, X. Q. 2008. Safety risk identification and assessment for Beijing olympic venues construction, Journal of Management in Engineering 24(1): 40-47.

doi:10.1061/(ASCE)0742-597X(2008)24:1(40)

Thomas, A. V.; Kalidindi, S. N. and Ananthanarayanan, K. 2003. Risk perception analysis of BOT road project participants in India, Construction Management and Economics 21(4): 393-407. doi:10.1080/0144619032000064127

Thomas, A. V.; Kalidindi, S. N. and Ganesh, L. S. 2006. Modelling and assessment of critical risks in BOT road projects, Construction Management and Economics 24(4): $407-$ 424. doi:10.1080/01446190500435275

Tieman, R. 2003. A revolution in public procurement: UK's private finance initiative, Finance Times, London, 24 November 2003, 4.

United Nations Economic Commission for Europe 2004. Governance in PublicPrivate Partnerships for Infrastructure Development, Geneva.

Wibowo, A. and Kochendörfer, B. 2005. Financial risk analysis of project finance in Indonesian toll roads, Journal of Construction Engineering and Management 131(9): 963 972. doi:10.1061/(ASCE)0733-9364(2005)131:9(963)

Yescombe, E. R. 2007. Public Private Partnerships - Principles of Policy and Finance, Elsevier. Great Britain.

Zhang, X. Q. 2001. Procurement of Privately Financed Infrastructure Projects. PhD Thesis, The University of Hong Kong, Hong Kong Special Administrative Region. Hong Kong.

\section{VIEŠOJO SEKTORIAUS PERSPEKTYVOS VIEŠŲJU DARBŲ PROJEKTUOSE - SPECIALISTŲ IŠ HONKONGO IR AUSTRALIJOS POŽIŪRIO PALYGINIMAS}

\section{E. Cheung, A. P. C. Chan, S. Kajewski}

$\mathrm{S}$ a n tra u a

Honkongas vienas pirmųjų įdiegè viešojo ir privataus sektoriaus partnerystès modelį vykdant stambius visuomeninius infrastruktūros projektus. Jo plètra Honkonge buvo sudètinga. Yra gana daug sričių, kurias būtu įdomu aptarti. Kaip sudètinio viešojo ir privataus sektoriaus partnerystès igyvendinimo tyrimo dalis atlikta vietiniu pramonininku iš viešojo sektoriaus apklausa dẻl viešųjų darbų pirkimų perspektyvų. Tarp apklaustujų buvo keturiolika vyriausybės pareigūnų ir patarèjų. Apklausos rezultatai parodè, kad daugelis respondentų iš Honkongo ir Australijos yra anksčiau atlikę tyrimus viešojo bei privataus sektoriaus partnerystès srityje. Abi respondentų grupès sutiko, kad viešojo ir privataus sektoriaus bendradarbiavimo projektai yra pranašesni efektyvumu, kompetencija ir valdymo gebejimais, lyginant su tradiciniais projektais. Taip pat abi respondentų grupés nurodè, kad viešojo ir privataus sektoriaus partnerystè labiau tinka verslo ekonominių projektų atveju. Respondentai mano, kad svarbiausias viešojo ir privataus sektoriaus partnerystės projektams yra rangovus apibūdinantis rodiklis. Respondentai išskyrè daug viešojo ir privataus sektoriaus partnerystès projektų kritinių sèkmės veiksnių. Du iš jų yra bendri abiem apklaustujų grupėms. Tai gerai apibrèžti projekto tikslai ir bendradarbiavimo 
dvasia, įsipareigojimai, tarpusavio pasitikejimas. Galiausiai nustatyta, kad vidaus valdymas yra paprastesnis Australijos apklaustose organizacijose, lyginant su Honkongo respondentais. Šiame straipsnyje nagrinejamas viešojo sektoriaus požiūris i viešojo ir privataus sektoriaus partnerystę Honkonge ir Australijoje. Tyrimas gali padèti atsakyti į klausimus, kylančius tiek akademiniame, tiek privačiame sektoriuje. Tad privatus sektorius gali geriau pasiruošti deryboms su viešuoju sektoriumi, geriau suprasti jų poreikius. Moksliniam sektoriui suteikiamos platesnès šios srities tyrimų perspektyvos.

Reikšminiai žodžiai: viešojo ir privataus sektoriaus partneryste, pirkimai, viešojo sektoriaus apklausos, Honkongas, Australija.

Dr. Esther CHEUNG is a Tutor in construction management at the Department of Building and Real Estate, The Hong Kong Polytechnic University. Her research interests include procurement systems, project finance, public private partnerships, construction safety and sustainable development.

Professor Albert Ping-Chuen CHAN is a Professor and Associate Head at the Department of Building and Real Estate, The Hong Kong Polytechnic University. He is a chartered / fellow member of the Chartered Institute of Building, the Australian Institute of Building, the Hong Kong Institute of Construction Managers, the Hong Kong Institution of Engineers and the Hong Kong Institute of Project Management, a member of the Australian Institute of Project Management, the Institution of Engineers Australia, the Australian Institute of Quantity Surveyors, Royal Institution of Chartered Surveyors, and a Registered Professional Engineer in Building. His research interests include project management and project success, project finance and public private partnerships, construction procurement and relationship contracting, construction industry development and construction safety

Professor Stephen KAJEWSKI is a professor and Head at the School of Urban Development, Queensland University of Technology. He is a member of the Institution of Engineers Australia, the Australian Institute of Building, and a Registered Professional Engineer (Queensland). His interests include the use of innovative information and communication technologies in the architecture, engineering and construction industries. 